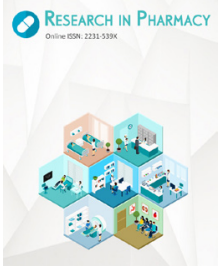

ISSN: $2231-539 X$

\title{
Allium stracheyi (Baker), the endangered and traditional medicinally important herb of Uttarakhand Himalaya, India: A Review
}

\author{
Manindra Mohan', S. Zafar Haider², Shiv Shanker Gautam ${ }^{3 *}$, Prashant Singh \\ 'Uttarakhand Council for Biotechnology (UCB), Haldi, U.S. Nagar, Uttarakhand, India, ${ }^{2}$ Centre for Aromatic Plants \\ (CAP), Selaqui - 248197, Dehradun, Uttarakhand, India, ${ }^{3}$ Department of Botany and Microbiology, Gurukul Kangri \\ University, Haridwar - 249404 Uttarakhand, India, ${ }^{4}$ Department of Chemistry, DAV (PG) College, Dehradun, \\ Uttarakhand, India
}

Received: January 21, 2019 Accepted: March 19, 2019 Published: March 24, 2019

*Corresponding Author: Dr. Shiv Shanker Gautam Email: gautam12shiv@gmail. com

\begin{abstract}
Allium stracheyi (Alliaceae), is the high-altitude growing plant, commonly known as Jamboo, and Dhungar in Uttarakhand, India. It is a good source of income for the tribal communities and cultivars of Uttarakhand with medicinally and economically importance. A. stracheyi has higher amount of fibre and protein contents with lower fat and carbohydrates. It is used in various ailments. Considering phytoconstituents studies revealed different types of compounds like hydrocarbons, terpenes, terpenoids and sulfur-containing components as volatile constituents. The present study aimed to provide a general review of the available literature of A. stracheyi on phytochemistry, biological activities and pharmacological uses with special reference to traditional and economic importance.
\end{abstract}

KEY WORDS: Allium stracheyi, phytochemistry, pharmacological application, sulfur contents, traditional importance

\section{INTRODUCTION}

India is a hotspot for a wide range of medically important genera and species that are being used in various traditional and modern medicines [1]. It covers more than 45,000 species of flora, on which most of species are not found anywhere else. There are more than 7,000 officially recognized plants in India with extensive medicinal properties [2]. The Indian Himalayan Region comprises only $11 \%$ of geographical area of India is well known for its medicinal and aromatic plants diversity [3]. It accounts for about $50 \%$ of total forest cover and $40 \%$ of the endemic species also [4].

The genus Allium is an endangered and ethnobotanically important herb with high medicinal value of Uttarakhand Himalaya. This genus consists of approximately 2685 species worldwide according to The Plant List [5], out of which only 30-36 species are found in India $[6,7]$. Traditionally, Allium spp. has been used by Bhotia tribal communities as spices from a long time. Generally, it is used in pickles, and treating health problems [8-10].

Allium stracheyi Baker (Alliaceae) is a perennial, small herb, up to $35 \mathrm{~cm}$ tall. The stem is leafy at the base, glabrous, leaves linear and flattened narrow, heads globose, pedicel shorter than the flower, tepals dark pink-reddish in colour [11]. It is locally known as Jamboo, Dhungar (Kumaun region) and Pharan (Garhwal region). This species occurs in Jammu Kashmir, Himachal Pradesh and Uttarakhand (India), Nepal and Pakistan at the elevation of 2500-3625 m [12-14]. A. stracheyi grows aside running water or dry open slopes and used as traditional vegetables [15]. A. stracheyi and A. wallichii with some other species were grown wildly in Tibet and its adjoining borders in Uttarakhand (Figure 1) [14] .

A. stracheyi has been included in the Red Data Book of Indian plants due to its indiscriminate collection and resulting threat to its existence [16]. Among Allium species, A. cepa and A. sativum are the most common species grown throughout the world. In historical point of view, German chemist T. Wertheim [17] identified sulfur containing oil as diallyl sulfide $\left(\mathrm{C}_{6} \mathrm{H}_{10} \mathrm{~S}\right)$ from garlic bulb. Later l-propenyl propyl disulfide [18], allicin [19], and alliin the derivative of the amino acid cysteine [20] with some other compounds were identified. A. stracheyi also contains sulfur rich compounds with antioxidant, anti-inflammatory and antimicrobial properties. The sulfur rich compounds are reported in reducing blood cholesterol [21]. Several other investigations have been performed and reported worldwide as

Copyright: $\odot$ The authors. This article is open access and licensed under the terms of the Creative Commons Attribution License (http://creativecommons.org/licenses/by/4.0/) which permits unrestricted, use, distribution and reproduction in any medium, or format for any purpose, even commercially provided the work is properly cited. Attribution - You must give appropriate credit, provide a link to the license, and indicate if changes were made. 


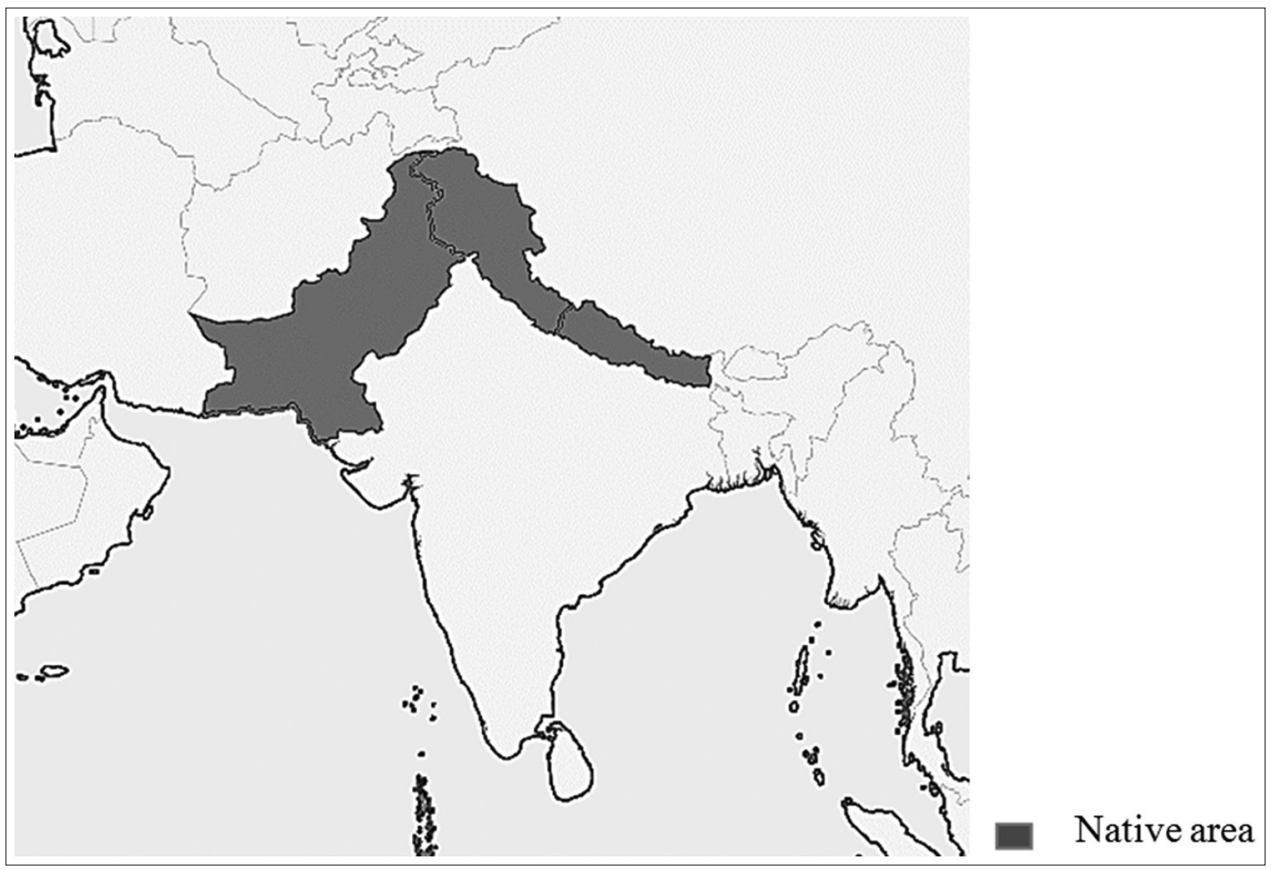

Figure 1: Distribution of Allium stracheyi Baker across the Asia including Nepal, Pakistan and West Himalaya (eMonocot, http://e-monocot.org, accessed on August 21, 2018)

well as in India to explore A. stracheyi significance and proved as medicinal plants. Therefore, this present study aimed to provide a general review of A. stracheyi on phytochemistry, biological activities and pharmacological uses along with special reference to traditional and economic repute.

\section{PHYTOCHEMISTRY}

The phytoconstituents are non-nutrient plant components or bioactive compounds. Herbal medicine is a complicated system of mixtures. Its preparations for medicinal usage contain different types of secondary metabolites or bioactive compounds. Various chemical and analytical techniques are helpful to understand the quality control and chemical constituents of herbal drugs. Allium species has been reported with various biologically active compounds such as phenolic acids, flavonoids, thiosulfinates, alkaloids, fixed oils, phytosterols, sulfur containing compounds and many more [1, $22-24]$.

\section{Nutritional Value}

A. stracheyi has high amount of fibres which helpful in maintaining blood glucose levels and its absorption. The nutritive value has the protein $(4.26 \%)$, fat $(0.1 \%)$, fibre (79.02\%), carbohydrate (3.18\%), calcium $(0.8 \mathrm{mg})$, phosphorus $(0.05 \mathrm{mg})$, iron $(0.50 \mathrm{mg})$, magnesium $(0.82 \mathrm{mg})$ and potassium $(0.95 \mathrm{mg})$ per $100 \mathrm{mg}[25]$ respectively.

\section{Volatile and Sulfur-Containing Compounds}

The phytochemical constituents of different extracts including petroleum ether, chloroform, methanol and aqueous extracts of A. stracheyi leaves figured out the presence of alkaloids, saponins, fixed oils, phytosterols, phenolics and flavonoids, tannins, and steroids [1,26]. A. stracheyi contains different types of compounds like hydrocarbons, terpenes, terpenoid etc. in which most of the compounds have sulfur as major content like 1,2-bis(methylthio) ethene (1), 2,4-dimethylthiophene (2), dimethyl disulfide (3) and dimethyl trisulfide (4) as the major volatile components (Figure 2) [11].

Another similar study on volatile composition of A. stracheyi reported 16-hentriacontanone (50.57\%), 4-nitrophenyl ester hexadecanoic acid (31.59\%), Heneicosane (28.84\%), (Z,Z,Z)9,12,15-octadecatrienoic acid (24.44\%), isobutyl octadecyl ester oxalic acid (47.51\%), 1-heneicosyl formate (13.79\%), vitamin E $(12.85 \%)$, Phytol (9.42\%), 12-Hydroxydodecanoic acid (8.74\%), (2-Bromocyclopropyl) benzene (8.25\%), Hexacosane (7.76\%), Tricosane (5.37\%), 1,5,9,13-Tetradecatetraene (5\%), (Z,Z,Z)9,12,15-Octadecatrien-1-ol (4.14\%), 11-Hexacosyne (3.09\%) and 3-Phenylthiolane 1,1-dioxide (5) as major constituents [22]. The identified volatile compounds i.e. (Z,Z,Z)-9,12,15octadecatrienoic acid also has been reported in curing cancer [27], having the anti-inflammatory and antioxidant properties [27, 28], palmitone the anxiolytic-like effect [29] and provide relief in spasmodic and arthritic pain [30].

\section{Total Phenolic and Cflavonoid Contents}

The total phenolic concentration (TPC) values of A. stracheyi extracts of whole plant are in range from $21.366 \pm 0.117$ to $22.374 \pm 0.117 \mu \mathrm{g} \mathrm{GAE} / \mathrm{mg}$ extract for hexane extract (100\%) and $23.009 \pm 0.093$ to $24.653 \pm 0.0968 \mu \mathrm{g} \mathrm{GAE} / \mathrm{mg}$ and total flavonoid content (TFC) ranged from $11.850 \pm 0.036$ to 12.714 $\pm 0.027 \mu \mathrm{g} Q \mathrm{QE} / \mathrm{mg}$ extract for hexane extract (100\%) and 12.824 \pm 0.044 to $13.421 \pm 0.017 \mu \mathrm{g} \mathrm{QE} / \mathrm{mg}$ extract for $100 \%$ methanol extract. The temperature is not showed any significant effect on 


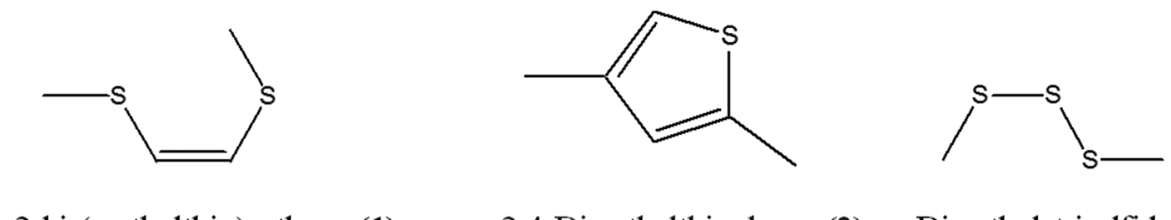

1,2-bis(methylthio) ethene (1)

2,4-Dimethylthiophene (2) Dimethyl trisulfide (3)

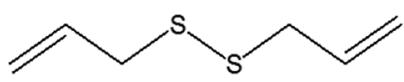

Diallyl disulfide (4)

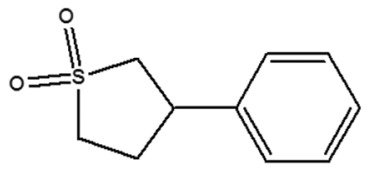

3-Phenylthiolane 1,1-dioxide (5)

Figure 2: Chemical structures of sulfur containing compounds of $A$. stracheyi

flavonoid concentration $(\mathrm{p}>0.05)$ and time showed significant increase $(\mathrm{p}<0.05)[31]$.

\section{ANTIOXIDANT ACTIVITY}

The antioxidant activity of A. stracheyi has been quite extensively studied. It is commonly measured using 1,1-diphenyl-2-picryl hydrazyl (DPPH) radical scavenging assay. Kumar et al. [32] has reported ethyl acetate fraction reported with $85 \%$ scavenging activity. Similarly, another study has determined the methanol extract $(74.654 \%)$ and hexane $(15.61 \%)$ radical inhibition in Kumaun Himalaya, India cultivar species [31].

\section{ANTIMICROBIAL ACTIVITY}

In last few years, the drug resistance in microorganisms is tremendously increased. Only it can be avoided by using plantbased compounds rather than existing synthetic antimicrobial agents [33]. The antimicrobial properties of A. stracheyi are quite interesting and still need to explore more against enteric, respiratory bacteria and commensal bacteria. Joshi and Khan [31] has reported the antimicrobial efficacy of hexane extract of A. stracheyi against Bacillus subtilis and Escherichia coli while methanol extract found resistant against $E$. coli at $0.5 \mathrm{mg} / \mathrm{ml}$. The antifungal study against Monascus ruber shows no significant inhibition.

\section{ANTI-INFLAMMATORY ACTIVITY}

Herbs are an excellent alternative to using anti-inflammatory drugs [34]. Although such drugs have an immediate effect, natural remedies-based herbs are effective over a longer period of time [35]. The anti-inflammatory and analgesic potential of A. stracheyi leaf extracts has been demonstrated by some workers. Ranjan et al. [26] reported methanol extract has significant reduction in inflammation $(61 \%)$ in Wistar rats.

\section{HEMOLYTIC PROPERTIES}

Hemolytic activity of plant extracts or plant derived compounds is an indicator of general cytotoxicity towards normal healthy cells [36]. A. stracheyi extracts exhibit the hemolysis activity confirmed by few workers. Six extracts including petroleum ether, benzene, n-butanol, ethyl acetate, 85\% ethanol and aqueous were reported for their hemolytic property with three different concentrations i.e. $50 \mu \mathrm{g}, 250 \mu \mathrm{g}$ and $500 \mu \mathrm{g}$. The n-butanol extract showed maximum amount of hemolysis whereas, the aqueous extract showed less hemolysis [1].

\section{HYPOGLYCEMIC ACTIVITY}

Allium species have effective results in management of diabetes in which it is administered i.e. extracts, juice, powdered, essential oil [37-39]. The ethanolic crude extract has been reported the hypoglycemic effect in alloxan induced male albino rats with significant reduction in blood glucose level, total serum lipids and cholesterol at $300 \mathrm{mg} / \mathrm{kg}$. The literature survey suggests that A. stracheyi still needs to explore the hypoglycemic activity.

\section{ANXIOLYTIC ACTIVITY}

Anxiety is an unpleasant state of internal trouble, often showed by nervous behavior, somatic complaints and rumination [40]. The benzodiazepines group belongs to anxiolytic substances act via the benzodiazepine receptors which are present on the GABAA pentametric complex. The clinical use of benzodiazepines is very limited with side effects like psychomotor impairment, sedation, myorelaxation, ataxia, amnesia and dependence liability [41 - 43]. Therefore, various medicinally important plants are used for therapeutic purposes to overcome central nervous disorders such as anxiety disorder [44 - 46]. Kumar et al. [47] reported the anxiolytic activity of A. stracheyi. The methanolic extract of A. stracheyi was studied for its anxiolytic property and the observations indicate that A. stracheyi imparts mild anxiolytic activity that affects emotion and cognitive behavior.

\section{GENETICS}

Mukherjee and Roy [48] reported the karyotype of some Allium species and results showed 8 as basic chromosome 
number except A. stracheyi. Cultivars of same species did not vary considerably in their karyotypes, although they were morphologically different to each other. In the continuation, RAPD and ISSR markers showed significant role for finding genetic diversity and phylogenetic analysis of Allium spp [49].

\section{ECONOMIC IMPORTANCE}

Dried leaves of A. stracheyi had the highest cost in the market (Rs. 3000 per kg) out of the thirty medicinal plants collected from Uttarakhand, India [50]. However, in local markets of Nepal dried A. stracheyi is sold at the rate of Rs. 300-400 per kg [51].

\section{OTHER PHARMACOLOGICAL USES}

A. stracheyi contains sulfur rich compounds with antioxidant, anti-inflammatory and antimicrobial properties. Boiled leaves are used for cattle and decoctions of leaves are used in cold and cough [14]. Dried flowers of A. stracheyi is used as a spice known as "Pharan" in Uttarakhand. It also acts as a tonic for digestive system and tonify the circulatory system. The boiled and fried bulbs in ghee are eaten for the treatment of cholera and dysentery. A. stracheyi have the wound healing properties in skin diseases [52]. Plant juice can be used as moth repellent. It is used also as flavoring agent as Onion flavor and flavor is due to presence of sulfur compounds. In the Kumaun Himalaya region, other Allium species is used as spice and condiment and for seasoning purposes.

\section{FUTURE DIRECTIONS}

The Allium species has been reported with various bioactive compounds such as alkaloid, flavanoids, phenolics, phytosterols etc. and sulfur containing compounds. The A. stracheyi and A. wallichii are two important medicinal plants used in Ayurvedic medicine and listed in database of Ayurveda plants prepared by Foundation for Revitalization of Local Health Tradition (FRLHT), Bangalore. A. stracheyi is a high-altitude growing plant which could be a good source of income for the tribal communities of hilly area and if it is cultivated on large scale through tissue culture and advanced biotechnological approaches, it can be prove as a good source of income for the cultivars. The state government can also play an important role to boost and promote the cultivation of economically important medicinal and aromatic plants in the state by giving the subsidy and training program through master trainers time to time under the skill development program.

\section{CONCLUSIONS}

Keeping the reference of present comprehensive literature studied, it can be concluded that A. stracheyi is a therapeutically as well as economically important herb of Uttarakhand. There is a need for propagation by tissue culture techniques so that it can be produced on large scale. The training towards cultivation, conservation and proper documentation of traditional knowledge can prevent its exploitation. Therefore, it is an urgent need for conservation, cultivation and sustainable exploitation of A. stracheyi as the precious resource of Uttarakhand Himalaya.

\section{ACKNOWLEDGEMENTS}

The authors are thankful to the Uttarakhand Council for Biotechnology (UCB), Haldi, U.S. Nagar, Uttarakhand, India for support, guidance and encouragement.

\section{CONFLICT OF INTEREST}

Authors declare no conflict of interest.

\section{AUTHOR'S CONTRIBUTION}

MM and SSG participated in designing the study, collecting the literature and drafted the manuscript. SZH analyzed the literature data and PS conceived and designed the review study.

\section{REFERENCES}

1. Mukherjee A, Rajasekaran C. In vitro hemolytic activity of Allium stracheyi Baker. J Pharm Res. 2010;3(5):1160-1162.

2. Sharma PC, Bhatia $V$, Bansal N, Sharma A. A review on Bael tree. Nat Prod Rad. 2007;6(2):171-178.

3. Samant SS, Butola JS, Sharma A. Assessment of diversity, distribution, conservation status and preparation of management plan for medicinal plants in the catchment area of Parvati hydroelectric project stage-III in north-western Himalaya. J Mt Sci. 2007;4(1):34-56.

4. Saxena KG, Rao KS, Sen KK, Maikhuri RK, Semwal RL. Integrated natural resources management: approaches and lessons from the Himalaya. Conservation Ecology 2001;5:1-14.

5. The plant list - Allium species. Available from: http://www. theplantlist.org/tpl1.1/search?q=allium + species Last accessed on 02 August, 2018.

6. Santapau H, Henry AN. A Dictionary of the Flowering plants in India. Pub. \& Inf. Directorate CSIR, New Delhi; 1973.

7. Karthikeyan S, Jain SK, Nayar MP, Sanjappa S. Flora Indicae Enumeratio: Monocotyledonae. Flora Indica 4. Botanical Survey of India. Howrah; 1989.

8. Kumari P, Singh BK, Joshi GC, Tewari LM. Veterinary ethnomedicinal plants in Uttarakhand Himalayan region, India. Ethnobot. Leaflets. 2009; 13:1312-1327.

9. Nautiyal S, Rajan KS, Shibasaki R. Environmental conservation vs compensation: explorations from the Uttaranchal Himalaya. Environ Inform Arch. 2004;2:24-35.

10. Samal PK, Dhyani PP, Bollo M. Medicinal plant resources in Nanda Devi biosphere reserve in the Central Himalayas. Indian J Tradit Know. 2010; 9:140-144.

11. Shah NC. Status of cultivated \& wild Allium species in India: a review. The Scitech. 2014;1(9):28-36.

12. Dasgupta S. Fascicles of Flora of India, Fascicle 23. Botanical Survey of India. In: Singh NP, Sanjappa M (Eds.), 2006; pp 1-48.

13. Rawat GS, Adhikari BS, Tiwari UK, Chandola S, Raut N. Medicinal plants of Garhwal region Uttarakhand: a baseline on the status and distribution. Wildlife Institute of India and Uttarakhand Forest Development Corporation, Dehradun, India; 2016.

14. Tiwari UK, Adams SJ, Begum SN, Krishnamurthy KV, Ravikumar K, Padma V. Pharmacognostic studies on two Himalayan species of traditional medicinal value: Allium wallichii and Allium stracheyi. Not Sci Biol. 2014;6(2):149-154.

15. Hanelt P. Alliaceae In Mansfeld's Encyclopedia of Agriculture and Horticultural Crops, Hanelt, P., Eds.; Springer-Verlag, Vienna. Vol. 4(3); 2001. ISBN: 3-540-41017-1.

16. Bisht VK, Negi JS, Bhandari AK. Check on extinction of medicinal herbs in Uttarakhand: no need to uproot. Natl Acad Sci Lett. 2016;39(3):233-235

17. Wertheim T. Investigations on garlic oil. Ann Chem Pharm. 
1844:51:289-315

18. Semmler FW. Essential oil of Onion (Allium cepa L.). Arch Pharm. 1892;230:443-448.

19. Cavallito CJ, Buck JS, Sulter CM. The antibacterial principle of Allium sativum. II. Determination of the chemical structure. J Am Chem Soc. 1944;66:1952-1954.

20. Stoll A, Seebeck E. Allium compounds I. Alliin, the true mother compound of garlic oil. Helv Chim Acta. 1948;31:189-210.

21. Abuajah $\mathrm{Cl}$, Ogbonna AC, Osuji CM. Functional components and medicinal properties of food: a review. J Food Sci Technol. 2015;52(5):2522-2529. doi: 10.1007/s13197-014-1396-5.

22. Joshi S. Studies on supercritical fluid extraction of organic compounds from Allium stracheyi Baker. PhD Thesis, Aligarh Muslim University, Aligarh, India; 2016.

23. Goncharov N, Orekhov AN, Voitenko N, Ukolov A, Jenkins R, Avdonin P. Organosulfur compounds as Nutraceuticals. In Nutraceuticals. Efficacy, Safety and Toxicity. 2016; pp 555-568. doi: 10.1016/B978-0-12-802147-7.00041-3.

24. Kuete V. Allium cepa. In Medicinal Spices and Vegetables from Africa. Therapeutic potential against metabolic, inflammatory, infectious and systemic diseases. 2017; pp 353-361. doi: 10.1016/B978-0-12809286-6.00014-5.

25. Dobhal R. Allium Stracheyi Baker. In spices of Uttarakhand. Uttarakhand State Council for Science \& Technology, Uttarakhand, India, 2015; pp 45.

26. Ranjan S, Jadon VS, Sharma N, Singh K, Parcha V, Gupta S, Bhatt JP. Anti-inflammatory and analgesic potential of leaf extract of Allium stracheyi. J Appl Sci Res. 2010;6(2):139-143.

27. Kim SJ, Chung WS, Kim SS, Ko SG, Um JY. Antiinflammatory effect of Oldenlandia diffusa and its constituent, hentriacontane, through suppression of caspase-1 activation in mouse peritoneal macrophages. Phytother Res. 2011;25(11):1537-1546. doi: 10.1002/ ptr.3443.

28. Agoramoorthy G, Chandrasekaran M, Venkatesalu V, Hsu MJ. Antibacterial and antifungal activities of fatty acid methyl ester of the blind-your-eye mangrove from India. Braz J Microbiol. 2007; 38(4):739-742. doi: 10.1590/S1517-83822007000400028.

29. Gonzalez-Trujano ME, Martinez AL, Reyes-Romirez A, Reyes-Trejo B, Navarrete A. Palmitone isolated from Annona diversifolia induces an anxiolytic-like effect in mice. Planta Med. 2006;72(8):703-707. doi: 10.1055/s-2006-931598

30. Carballo Al, Martinez AL, Gonzalez-Trujano ME, Pellicer F, VenturaMartinez R, Diaz-Reval MI, Lopez-Munoz FJ. Antinociceptive activity of Annona diversifolia Saff. leaf extracts and palmitone as a bioactive compound. Pharmacol Biochem Behav. 2010;95(1):6-12. doi: 10.1016/j.pbb.2009.11.017.

31. Joshi S, Khan MA. Ultrasound assisted extraction technique: Study of the biological properties of Allium stracheyi Baker. Internat J Proc \& Post Harvest Technol. 2016;7(1):85-95. doi: 10.15740/HAS/ IJPPHT/7.1/85-95.

32. Kumar S, Pangti J, Thakur S, Upadhyay N, Jain M. Antioxidant and wound healing potential of standardized ethyl acetate fraction (AS-3) of Allium stracheyi in Rats. Int J Biol Pharm Allied Sci. 2015;4(12):6467-6480.

33. Shah PM. The need for new therapeutic agents: what is in the pipeline? Clin Microbiol Infect. 2005;11:36-42. doi: 10.1111/j.14690691.2005.01141.x.

34. Rupasinghe HPV, Arumuggam N, Amararathna M, De Silva ABKH. The potential health benefits of haskap (Lonicera caerulea L.): Role of cyaniding-3-O-glucoside. J Funct Foods. 2018;44:24-39. doi: 10.1016/j.jff.2018.02.023

35. Furst R, Zundorf I. Plant-derived anti-inflammatory compounds: hopes and disappointments regarding the translation of preclinical knowledge into clinical progress. Mediators Inflamm. 2014;Article id: 146832. doi: 10.1155/2014/146832.

36. Da Silva E, Shahgaldian P, Coleman AW. Haemolytic properties of some water-soluble para-sulphonato-calix-n-arenes. Int J Pharm. 2004;273(1-2):57-62.

37. Eidi A, Eidi M, Esmaeili E. Antidiabetic effect of garlic (Allium sativum L.) in normal and streptozotocin-induced diabetic rats. Phytomedicine. 2006; 13:624-629. doi: 10.1016/j.phymed.2005.09.010.

38. Akash MSH, Rehman K, Chen S. Spice plant Allium cepa: Dietary supplement for treatment of type 2 diabetes mellitus. Nutrition. 2014;30:1128-1137. doi: 10.1016/j.nut.2014.02.011.

39. Mohamed SM, Jaleel GAA, Abdallah HMI, Bashandy SAE, Salama AB, Mahmoud AH. Hypoglycemic, hypolipidemic and antioxidant activities of Allium porrum leaves extract in streptozotocin-induced diabetic rats. Int J Pharmtech Res. 2016;9(11):187-200.

40. Seligman MEP, Walker EF, Rosenhan DL. Abnormal psychology, $4^{\text {th }}$ Ed. New York: W.W. Norton \& Company; 2000.

41. Czobor P, Skolnick P, Beer B, Lippa A. A multicenter, placebocontrolled, double-blind, randomized study of efficacy and safety of ocinaplon (DOV 273, 547) in generalized anxiety disorder. CNS Neurosci Ther. 2010;16 (Suppl 2):63-75. doi: 10.1111/j.17555949.2009.00109.x.

42. Emamghoreishi M, Khasaki M, Aazam MF. Coriandrum sativum: evaluation of its anxiolytic effect in the elevated plus-maze. J Ethnopharmacol. 2005;96(3):365-370.

43. Doukkali Z, Taghzouti K, Bouidida EH, Nadjmouddine M, Cherrah Y, Alaoui K. Evaluation of anxiolytic activity of methanolic extract of Urtica urens in a mice model. Behav Brain Funct. 2015;11:19. doi: 10.1186/s12993-015-0063-y

44. Verma R, Hanif K, Sasmal D, Raghubir R. Resurgence of herbal antihypertensives in management of hypertension. Curr Hypertens Rev. 2010;6(Suppl 3):190-198. doi: 10.2174/157340210791936705.

45. Carlini EA. Plants and the central nervous system. Pharmacol Biochem Behav. 2003;75:501-512. doi: 10.1016/S0091-3057(03)00112-6.

46. Faustino TT, Almeida RB, Andreatini R. Medicinal plants for the treatment of generalized anxiety disorder: a review of controlled clinical studies. Rev Bras Psiquiatr. 2010;32(Suppl 4):429-436.

47. Kumar S, Joshi H, Chandra JNNS, Bahuguna P, Kedia VK, Kumar R. Effect of Allium Stracheyi on behavior of Zebrafish: a pharmacological approach. Sch J App Med Sci. 2015;3(9D):3356-3363.

48. Mukherjee A, Roy SC. Karyotype analysis of five species of Allium. Indian Journal of Fundamental and Applied Life Sciences. 2012;2(2):374-383.

49. Mukherjee A, Sikdar B, Ghosh B, Banerjee A, Ghosh E, Bhattacharya M, Roy SC. RAPD and ISSR analysis of some economically important species, varieties, and cultivars of the genus Allium (Alliaceae). Turk J Bot. 2013;37:605-618.

50. Kala CP. Medicinal Plants in Active Trade at Haridwar City of Uttarakhand State in India. Medicinal and Aromatic Plants. 2015;4:204. doi: 10.4172/2167-0412.1000204.

51. Chhetri HB, Gupta VNP. A survey of non-timber forest products (NTFP) in upper Mustang. Scientific World. 2007;5:89-94. doi: 10.3126/ sw.v5i5.2663.

52. Uttara B, Singh AV, Zamboni P, Mahajan RT. Oxidative stress and neurodegenerative diseases: a review of upstream and downstream antioxidant therapeutic options. Curr Neuropharmacol. 2009;7(1):65-74. doi: 10.2174/157015909787602823. 